\title{
Influence of Strategic Leadership Style on Academic Performance of National Schools in Kenya
}

\author{
Clare Gakenia $^{1}$, Prof. Paul Katuse ${ }^{2}, \&$ Dr.Peter Kiriri ${ }^{3}$ \\ ${ }^{I}$ Corresponding Author and Doctorate Student at United States International University, Africa \\ ${ }^{2,3}$ Lecturers at United States International University, Africa
}

\begin{abstract}
Strategic leadership, is an ability by the leader to anticipate, prepare and position for the future; It has also been observed to be the leaders ability to anticipate, create a vision, empower others and exercise flexibility, to create a strategic and viable future of the organization. Leaders who are strategic leaders formulate the goals and strategies for the organization. They do this by developing structures and processes that impact the present and future performance of the organization. They are experienced, senior leaders that are knowledgeable and have the ability to create a vision and execute plans and make significant decisions in the dynamic environment. This study sought to examine the influence of strategic leadership style on academic performance of National Schools in Kenya. The study recommended that the national schools should emphasize the role of strategy leadership styles with view of improving on the academic performance of their schools. However strategy leadership styles variables alone cannot influence the academic performance of their schools as strategy leadership styles were found not to have a significant influence on the academic performance with a $P$ value of 0.307. This was largely attributed to the fact that the national schools have a set policies and procedures in which leaders are required to adopt hence little variances in terms of leadership styles in various schools and leadership styles for an individual is hence not a key determinant of academic performance in national schools. School should however focus on leadership traits, resource availability and strategy execution plan besides variables of leadership styles.
\end{abstract}

Keywords: Academic Performance, Strategic Leadership Style,

\section{Introduction}

According to Northhouse (2007) Leadership is that process where an individual impacts on a group of individuals with the intent of achieving a common goal. Various previous studies have firmed up that leadership styles has a direct relationship with performance - school of thought. The Upper echelon theory Hambrick \& Mason (1984) suggests that organizations are reflections of top managers' cognitions and values. Hambrick \& Finkelstein (1987) imply that the amount of discretion enjoyed by top managers will moderate the relationship between their strategic choices and organizational outcomes. The greater the discretion the more the impact the leaders choices will have on organizational outcomes. Cannella \& Monroe (1997) define discretion as a summary of variable that incorporates environmental constraints, organizational factors and individual differences as reflected by demographic and personality characteristics.

In a rapidly changing and highly demanding world there is continual high stakes in the academia fraternity. Learning institution are expected to continually produce top performing students. The leadership of this schools in equal measure is expected to continually lead the organizations ethically and significantly. The values vested by this should go beyond the present to the future. With the ever increasing demands to the principals in relation to the academic deliverables, it is difficult for most of the leaders to see beyond the academic performance at present. Most are concern with the now. However the successful principals will be those that look beyond the now.

Strategic leadership, is an ability by the leader to anticipate, prepare and position for the future (Serfontien \& Hough, 2011); It has also been observed to be the leaders ability to anticipate, create a vision, empower others and exercise flexibility, to create a strategic and viable future of the organization (Kleijnen, Dolmans, Muijtjens, Willems, \& \& Van Hout, 2009). Leaders who are strategic leaders formulate the goals and strategies for the organization. They do this by developing structures and processes that impact the present and future performance of the organization. (Boal K. \&., 2001). They are experienced, senior leaders that are knowledgeable and have the ability to create a vision and execute plans and make significant decisions in the dynamic environment (Guillot, 2003). This strategic leaders have the direct influence on leadership at present and also are concerned with the future of the organization. It is therefore appropriate to firm up that there being many contributory factors to the success and the failure of the organization at large according to Bass (2009); leadership is often regarded to as the single most critical factor in the success of failure of institutions. Different leadership styles have varying impact on the performance of institutions in both long and short term. Amongst the various leadership styles, strategic leadership has been observed to have immediate and long term impact in 
the organization. Great leaders are arbitrated by the impact they legacy of their tenure. A vibrant, vital organisation that is competitive and determined to excel is, an essential component for a leader (Boal \& Hooijberg, 2001). This means the leaders need to get their teams working in sync, understanding and embracing the vision and goals set ahead.

Strategic leadership has been defined as determining where an organization was heading and how to get there. According to the Cheng, 2000, strategic leadership largely entails strategic and 'long-range' forecasting, and was a process that was viewed to mainly belong to the upper management mainly. However progressively it is clear that strategic leadership not just about having the vision but also achieving the desired future. Strategic leadership acknowledges presence of uncertainty of the expected future and it accordingly develops strategies to tackle the unknown (Quong \& Walker, 2010). Of the various impact of strategic leadership, alignment is considered to be an integral component of this type of leadership. According to Khadem (2008: 29), alignment is crucial to success. Alignment is that state in which strategy, employees, customers and key processes work in sync to drive growth and profits. Aligned organizations have satisfied customers, fulfilled employees and superior services and products. Further they have better returns to the shareholders (Labovitz, 2004: 30). The right planning results in the right work structures resulting in the development of cohesion amongst team members, which results in the positive output. An important correlate of effective performance is cohesiveness of the group. Therefore development of alignment among team members is an important part of team management. The planning is derived from the goals and objectives of all the stakeholders of the school. The strategy on the other hand is guided by the leadership of the organization. The synergy between the two components results in the success of the organization. The significance of strategic leadership has been deeply researched but in relation to the key factors within this leadership that result in success are still progressively being researched. These questions give rise to the problem statement and objectives addressed in this study. What key factors of the strategic leader make the difference in this competitive landscape? It would seem that some leaders definitely do influence organizational performance (Smith, Carson \& Alexander, 1984: 765). In this context this inherently means that the head teachers are congruently responsible for the school performance. The choices in policy, procedure and strategy they make; determining the success or failure of the school. The principal as the leader of the school is invariable impacted by discretional factors that may influence the outcome; his ability in absorbing and adapting to this factors determine if he will success or fail. There are among the many components of leadership that congruently contribute to the success or failure of the organization. Several reasons indicate that there should be a relationship between leadership style and organizational performance. Zhu et al. (2005), suggest that a visionary type of leadership will result in high levels of cohesion, commitment, trust, motivation, and hence performance in the new organizational environments. Visionary leaders will generate a strategic vision for an expected future state, communicates the vision, model the vision, and ensures a buy-in towards the vision (Avolio, 1999; McShane and Von Glinow, 2000). On the other hand, transactional leadership helps organizations achieve their current objectives more efficiently by linking job performance to valued rewards and by ensuring that employees have the resources needed to get the job done (Zhu, Chew, \& Spangler, 2005). Mehra, Smith, Dixon, \& Robertson, (2006) argue that when some organizations seek efficient ways to enable them excel in their performance, the key is to focus on the effects of leadership. On the other hand, substantial current literature studying school leadership postulates that leadership has a minimal direct impact on student achievement (Rose \& Gray, 2006). Kruger, Witziers, \& Sleegers (2007) hypothesised that leadership is no longer proposed as having a direct influence on academic outcomes, but indirectly influences instructional organization and culture of the learning institutions. A clear understanding of the impact leadership on performance is hence important as research has indicated as it is considered to be a critical driving force for improving an organization performance. A review of the educational leadership in our country details that the school leadership structure in Kenya is hierarchical with the principal at the top then the deputy principal, the director of studies, heads of departments, teachers then students. In relation to the governing of the school there are two legal bodies tasked with managing the school and parent students' interest. The board of governors (BOG) is tasked with the management of the school as per the Education Act cap 211 and the Parent Teacher Association was established with the role of addressing the school needs by raising funds to facilitate the school projects. According to the Head Teacher's manual the principal is responsible for the planning, organizing, directing, controlling, staffing, innovation, coordinating and motivating for the actualizing the education goals and objectives of the institution and country. He is the key decision maker and determinant of the system of planning in the school. To this end in accordance with Goddard, Hoy, \& Hoy, (2000) Goddard and Emerson (1993) wherein he asserts that there is a strong relation between the quality of a school and leadership, the performance of the school is largely determined by leadership quality. Fry (2003) defines leadership as provision of guidance in strategy to offer inspiring motivation and to enhance the staff's prospective for growth and development. Studies have suggested that effective leadership behaviours can facilitate the improvement of performance when organizations face these new challenges (McGrath and MacMillan, 2000; Teece, Pisano and Shuen, 1997). 
Success in the national public high schools is measured mainly by performance of students' in external examinations. Examinations are used among others to measure the level of candidates' achievements and clarify the candidates' level of education and training. They also provide the basis for evaluating the curriculum both at local and national level. A student's performance in any examination is dependent such variables include the type of school and the facilities in this schools, the level of qualification of the teachers, the academic panache, the qualification and leadership style by the head teacher, the school environment and the teachers (Lydia \& Nasongo, 2009). The main role of the instructional leader is to ensure that the mission achievement of the established mission through creating a good environment for the schools (Lezotte, 2001). According the (Graddy \& Stevens, 2005) there was a negative relationship beween the pupil teacher ration and the academic performance of the students. Munir \& Khalil (2016) established that the effect of the leadership behaviour of principals on student did not have a significant impact on the performance of the students

Amongst the vast studies conducted in Kenya in relation to Leadership styles there is yet to be a study on strategic leadership alignment on academic performance. Mang'olla (1977), Asunda (1983) and Kariuki (1988) researched on leadership behaviour but not on styles and performance. Ursula (2000) researched on the influence of leadership styles on academic performance in Nairobi province, Njuguna (1998) researched on the relationship between head teacher's leadership styles and general performance of KCSE examination in Nairobi province. Mwamuye (2012) studied the role of leadership in performance of primary schools in Kenya. Musungu \& Nasongo (2008) studied on the impact of the head-teacher's instructional role in academic achievement in secondary schools. Okelo (2011) researched on influence of Head teachers' strategies in Starehe district. Akoth (2011) investigated the influence of head teacher's leadership style on job satisfaction among public secondary schools teachers. Nyongesa (2014) studied on head teacher's leadership style on school on school academic performance in Kenya Secondary Schools. Nyamboga et al. (2014) evaluated the impact of leadership styles on the performance of public secondary schools in the national examination in the Tana River County, Kenya. However there is no research which has explored strategic leadership alignment correlation with academic performance in relation to schools in Kenya.

Various studies have varying perspectives in relation to the effectiveness of a school; particularly in regard to performance. Martimore, (1998) maintains that effective schools are the schools wherein the students score higher on achievement text that might be expected from the characterization at entry whilst Hoy and Miskey (2008) reckons that schools effectiveness is usually judged through academic performance results. In the most general sense, school effectiveness refers to the level of goal attainment of a school (Prof.Scheerens, 2013). According to Schreerens (1999) school effectiveness research, the context of school performance is not limited to ranking alone it is also based on value add to the students. However research tradition in educational effectiveness has varied according to the emphasis that is put on the various antecedent conditions of educational outputs Amongst the five factors related to effectiveness in schools, according to (Edmonds, 1979) frequent evaluation of pupil progress was such a factor related to school effectiveness. Academic evaluation of the students' performance is an aspect that is undisputedly accepted as parameter that is used to determine the effectiveness a school. In our country the national examinations provide a standardized evaluation of the students across the country. The performance of the students on this examination in relation to the school, guides the question of how effective was the school in having equipped the students for the examinations. Thus it would be ideal to conclude that the performance of the students in a particular school is directly relation to the effectiveness of the institution. Numerous reviews on school effectiveness have been published since the late seventies. Notably there is a fairly large consensus on the main categories of variables that are distinguished as effectiveness enhancing conditions in the reviews, more so when earlier and more recent reviews are compared. Schreerens (1999) highlights the consensus being largest in relation to the following factors: achievement orientation, co-operation, educational leadership, frequent monitoring, time, opportunity to learn and structure. Of the six factors highlighted as factors that enhance the school effectiveness, the focus of this study will mainly be on leadership and evaluation of how in particular strategic leadership impacts effectiveness. To this end for the purpose of this study school performance in relation to the achievement in the national exam KCSE is considered to be academic performance.

A strategically-focused school is one that in regard to educationally effective in the short term but has clear guidelines, policies and procedures to convert the moral and the vision into an education that is fulfilling, challenging and sustainable in the long run. (Davies, Davies, \& Ellison, 2015).In the quest to establish the impact of strategic leadership alignment on academic performance, strategic leadership alignment constituents' namely strategic leadership style, strategic leadership traits and strategy execution will be part parameters for impact on academic performance to determine what component in strategic leadership is critical to the academic performance of the students.

According to Greenwald, Hedges, \& Laine (1996), broad range of resources positively impacted the performance outcomes of students. Of the resources under consideration in the various studies, are teachers availability, funds, amenities, laboratories. Each of this resources is considered to have varying relationships 
with the performance of the students.. The study will use resource availability as a moderating variable. The role of resources in performance of firms cannot be undermined. Resource dependence perspective provides valuable explanation on the interaction between organizations and their environment, how organizations cope with environmental constraints, and how the environment and different strategies affect organization's outcomes. Macedo \& Pinho, (2006) are of the view that organizations are not isolated entities free from external pressures and acting on their own will. Instead they consistently in direct or indirect interaction with other entities in the environment where resource exchange relationships take place. According to the resource dependence theory, institutions are dependent on the resources within their environment (Fadare, 2013). Resources include but not limited to assets, capabilities, organizational processes, information, and knowledge that contribute to improved organizational efficiency and effectiveness (Daft, 2001). In this study the resources that under consideration for the moderating variable in the quest to determine if they have an impact on performance are infrastructure, government funding and teachers.

\section{Strategic Leadership Theory}

\section{Literature Review}

The competencies of a strategic leader can be categorized into two; in relation to the organization and individual abilities. A conclusively afore mentioned, a strategic leadership the leader has to make decisions in relation to the future taking consideration of the present and the probable future. He has to ensure that the strategies adopted allow for the dynamism of the expected market environment. To be able to undertake this role the leader must understand the relationship between his ability and the value creation. Davies (2004) argues the key to that strategic focus is the quality of the strategic leadership in the school. Such a leader should have the organizational ability to be strategically orientated; able to translate strategy into action; can align people and organizations toward a goal; is able to determine effective strategic intervention points; and develops strategic competencies.

According to Ireland and Hitt (2002) there is a definite relationship among the leadership's characteristics, an organization's strategies, and its performance. When the board of directors/ governors and the leadership in the instititution are involved in shaping an organization's direction, the organization generally improves its performance critical element of strategic leadership and organizational performance, is the ability of leadership to manage and utilize the organization's resource portfolio. This includes integrating resources to create capabilities and leveraging those capabilities through strategies to build competitive advantages and high performance.

\section{Criteria of effective Strategic Leadership}

The search for strategic leadership competencies has been a continual process. In the early 1980s there was the feel that leadership had been exhaustively explored however some researchers felt that there was more to be explored leading to a culmination point that led to studies on transformational, visionary leadership, organizational change, charismatic leadership and thereafter strategic leadership. During this phase the competencies that were identified for strategic leadership were vast. Steve Covey states that strategic leaders have basic functions; path finding, aligning and empowering (Wong, Gerras, Kidd, Pricone, \& Swengros, 2003; Hayat, Hussain, \& Sardar; Weiss, 2006).

Kim Boal and Robert Hooijberg distill the essence of strategic leadership to three factors-effective strategic leaders must create and maintain absorptive and adaptive capacity in addition to obtaining managerial wisdom (Wong L.et al., 2003; Compton, 2008;Duursema, 2013). According the Army Leadership the Army's doctrinal leadership manual there are 41 competencies addressing the direct, organizational and strategic levels (Wong L.et al., 2003; (Head Quarters Department of the Army , 2015). A review of the detailed literature and other literature details vast array of competencies of strategic leadership. Part of the difficulty encountered by anyone desiring to adjust leader development or education efforts is the broad array of competencies presented in the literature (Wong et al., 2003). Strategic leaders are concerned with not just managing the present status, but also setting up a framework of where the organizations should be in the future (Davies \& Davies, 2004). Effective strategic leadership practices also includes focusing attention on outcomes and processes; seeking to acquire and leverage knowledge; fostering learning and creativity; anticipating internal and external environmental changes; maintaining a global mindset; meeting the diversity of the interests of the multiple stakeholder; building for the long-term while meeting short-term needs; developing human capital (Bass, 2007). The Davis and Davis (2004) model has this components describing the strategic leader within a learning institutions environment. 


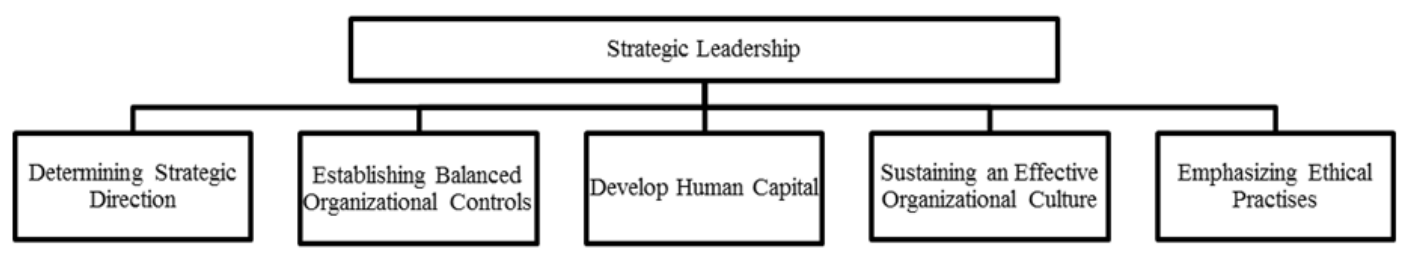

Figure 1 Strategic Leaderships Influence on the Management Process

Source: Hoskisson, Hitt \& Ireland (2004).

Hoskisson, Hitt, \& Ireland (2004) defines strategic leadership as the managerial ability to anticipate, envision, maintain flexibility, and empower others to create strategic change. They identified key activities that top management should focus on to contribute to the performance of the organization. This are determination of effective strategic direction, development of human capital, emphasizing on ethical practises, establishment of balanced organizational controls, exploiting core competencies and sustaining an effective organization culture.

Strategic Leadership connotes focus on the management of an overall enterprise, not just a small unit; it also implies substantive decision-making responsibilities, beyond the interpersonal and relational aspects usually associated with leadership (Finkelstein, Hambrick, \& Cannella Jr, 2009). Rowe (2001) defined strategic leadership as the ability to influence others to voluntarily make day-to-day decisions that enhance the long-term viability of the organization, while at the same time maintaining its short-term financial stability. Amos (2007) defines strategic leadership as the ability to understand the entire organization and the environments within which they operate and using this understanding to create strategic change through other people so as to position the organization in the environment for both short-term stability and long-term viability. A strategic leader makes decisions every day that impact people of different cultures, agencies, agendas, personalities, and desires. It requires the devising of plans that are feasible, desirable, and acceptable to one's organization and partners whether joint, interagency, or multinational (Junarso, 2009). It is thereby crucial that strategic leaders should have the ability to make sound, reasoned decisions specifically, consequential decisions with grave implications. Since the aim of strategy is to determine the ends, choose the best ways, and apply the most effective means (Col Guillot, 2003). "Strategic leadership involves activating agendas that infuse organizations not just with change visions, but also with sustained capacity for change implementation". Further, strategic leaders display dissatisfaction with the present, absorptive capacity, adaptive capacity and wisdom (Duursema, 2013).

Harray (2008) indicates that strategic leadership involves ability of leaders to have wisdom and vision to create and execute plans and make consequential decisions in the volatile, uncertain, complex and ambiguous strategic environment. Similarly, Mungonge (2014) notes that strategic leadership involves the creation of environment that supports achievement of organizational goals and roles of monitoring external environment to take advantage of opportunities as well as defend against threats. Serfontein (2010) examined the Impact of Strategic Leadership on the Operational Strategy and Performance of Business Organizations in South Africa. The study noted that strategic leadership is about the ability to position the organization to meet its future objectives through mobilization and focusing of resources in the action steps required for this achievement. The ability to position the organization's future is recurrent in other definitions of strategic leadership. Njiri (2016) indicates that strategic leadership refers to the ability of leaders to create and recreate reasons for organization's continued existence through meeting today's organizational deliverables while constantly monitoring changes within the organizational environment. This environmental scanning involves the examining factors that may undermine the operations of the organization as well as any opportunities that are present in the environment. While still emphasizing on the positioning the organization for the future.

\section{Strategic Leadership style}

The search for strategic leadership competencies has been a continual process. In the early 1980s there was the feel that leadership had been exhaustively explored however some researchers felt that there was more to be explored leading to a culmination point that led to studies on transformational, visionary leadership, organizational change, charismatic leadership and thereafter strategic leadership. During this phase the competencies that were identified for strategic leadership were vast. Steve Covey states that strategic leaders have basic functions; path finding, aligning and empowering (Wong, Gerras, Kidd, Pricone, \& Swengros, 2003; Hayat, Hussain, \& Sardar; Weiss, 2006).

Kim Boal and Robert Hooijberg distil the essence of strategic leadership to three factors-effective strategic leaders must create and maintain absorptive and adaptive capacity in addition to obtaining managerial wisdom (Wong L.et al., 2003; Compton, 2008;Duursema, 2013). According the Army Leadership the Army's doctrinal leadership manual there are 41 competencies addressing the direct, organizational and strategic levels (Wong L.et al., 2003; (Head Quarters Department of the Army ,2015). A review of the detailed literature and other literature details vast array of competencies of strategic leadership. Part of the difficulty encountered by 
anyone desiring to adjust leader development or education efforts is the broad array of competencies presented in the literature (Wong et al., 2003). This research mainly focuses on Davies organizational and individual competencies (Davies \& Davies, 2004).

Their view is that the strategic leaders are concerned with not just managing the present status, but also setting up a framework of where the organizations should be in the future (Davies \& Davies, 2004). Effective strategic leadership practices also includes focusing attention on outcomes and processes; seeking to acquire and leverage knowledge; fostering learning and creativity; anticipating internal and external environmental changes; maintaining a global mind-set; meeting the diversity of the interests of the multiple stakeholder; building for the long-term while meeting short-term needs; Developing human capital (Bass, 2007). The Davis and Davis (2004) model has this components describing the strategic leader within a learning institutions environment. These concepts are in line with Ireland and Hitt's (1999: 48-52) critical criteria for effective strategic leadership

\section{Strategic Leadership - Strategic Oriented}

The function of strategy is to translate the moral purpose and vision into reality. School leaders articulate the definition of the organization's moral purpose which can be considered as 'why we do what we do'. The values that underpin this moral purpose are linked to the vision setting 'where we want to be and what sort of organization we want to be in the future these ability to consider long -term future is termed as strategic orientation; generally looks at least five to ten years into the future (Beare, 2001; Hitt L.M, D.J, \& X.G, 2002 Hagen, Hassan, \& Amin, 1998). Strategic orientation is a way of developing strategies, it involves analysis of strengths, weaknesses, opportunities and threats. It to Naver \& Slater (1990) a number of realistic alternatives and provides a prioritization. According a firms strategic orientation reflects that strategic direction impelemented by a firm to create the proper behavious of the continous superior performances of the business (Liu \& Fu, 2011).

According to Porter as cited by Hammonds (2001) chief strategist of an organization have to be the leaders such as the CEO. This is due to the emphasized inking has stressed the notion of empowerment, of pushing down and involving many people. This is crucial, but empowerment and involvement do not apply to the ultimate act of choice. There is a link between the strength of the leader in making definite decisions and the effectiveness of the strategy. According to Hammonds (2001), there is a striking relationship between really effective strategies and really strong leaders.Hence provision of strategic direction in strategic leadership includes a component of strategic direction and provision vision. The development of organizational vision and the ability to manage the change engendered by visions represent core organizational competencies that foster a competitive advantage for organizations (Zaccaro\& Banks, 2004: 367). The principal of the school as the leader must be able to communicate the vision of the organization in order for him to succeed in cascading the vision. He must be a visionary, seeing beyond the here and the now as it is a critical element for anyone in a leadership position because it is closely aligned with future-directed goals (Orndoff, 2002).Strategy, therefore, is translating the vision and moral purpose into action. It is a delivery mechanism for building the direction and the capacity for the organization to achieve that directional shift or change. This translation requires a proactive transformational mind-set which strives for something better rather than the maintenance approach of transactional leadership. A significant factor in organizations that have successfully transformed themselves from those that labour mightily to produce little more than business as usual, is the possession of a long-term strategic intent that aligns the actions and beliefs of everyone in the organization towards a challenging goal.

\section{Ability To Translate Strategy Into Action}

Strategic leaders make and communicate decisions for their organizations' future (Bass, 2007: 36). They formulate the organizations' goals and strategies; develop structures, processes, controls and core competencies for the organization; manage multiple constituencies; choose key executives; groom the next generation of executives provide direction with respect to organizational strategies: maintain an effective organizational culture; sustain a system of ethical values; and serve as the constituencies, as well as negotiate with them. Strategic implementation is the most important yet the most difficult part of strategic leadership (Brecken, 2004). According to David \& David (2004) Kaplan and Norton (2001) argue that strategy can be translated into action through the use of 'strategy maps' and 'balanced scorecards' as they 'provide a framework to describe and communicate strategy in a consistent and insightful way'. Execution of strategy entails the transformation of the current frame of mind of the institution. When executing change / translating the culture of the organization; there are two principal aspects that have to change; the culture - the mind-set and the behaviour of the people within the organization. Wilson (1997) states 'organizational change has two principal aspects; change in mission and strategy and change in culture and behaviour" to ensure alignment. According to Tichy and Sharman (1993) there is a three stage process to transform the strategy into action; Firstly there is the awakening stage; it involves building an agreement within the school that a continuation of the current way of working will not deliver the effectiveness desired in the future. Secondly is the envisioning stage. This entails 
the creation of a clear picture of what the new way of operating looks like and creation of the capacity to achieve it. Finally there is the new architecture of the new institution or in this case a school then emerges. It is important to remember that strategy is a neutral delivery vehicle. If you have a poor vision and a dubious moral purpose then a good strategic process and approach may effectively deliver it for you (Davies, 2015). This means that the strategy's existence is not in a vacuum environment it requires be part of a wider process of values-led leadership and futures visioning.

\section{Strategic Leaders The Ability To Align People}

Alignment in an organization suggest that there is strong connnection between the employees activities, organization structures and product offering. Chorn, 1991; Labovitz \& Rosansky, 1997 stated that the strength of the alignment theory is its ability to pool the organization members into a more logical and cohesive structure. They concurred that the alignment is essential because it "provides a way for capturing the best approaches by linking strategy and people and integrating them with customers and process improvement". The strategic leader in the schools- the principal has the role to align the staff. The principal should govern the strategic conversation and dialogue relating to the issues and concerns facing school and the future outlook of the school. These conversations enable people to develop a strategic perspective of what the school might become. Further engagements in discussions evokes staff participation which leads to greater participation and increase in understanding. The process of greater awareness and participation in discussion is a key way which develops alignment. This is because the leader aligns by motivating individuals in the organization as they develop a strategic cause in which individuals contribute leading to increased commitment and effort. Gratton (2000) advocates developing 'emotional capabilities, trust-building capabilities and capabilities to build a 'psychological contract' as the means of engaging and motivating staff. When people are involved and part of something they believe in they are better able to identify with the short and long term goals of the strategy. Building commitment to values and long-term ambitions provides individuals with a vision and sense of direction that allows them to put short term problems and challenges into context (Davies \& Davies, 2004).

\section{Strategic Leaders Are Able To Effectively Determine Effective Intervention Points}

Additionally in creating alignment within the organization the leader should building capability within this organization. This is achieved through the strategic conversation and enhanced participation building greater personal and organizational capability and capacity. Given that the major resource of any organization is the quality of its human capital, then enhancing that quality should be a major organizational focus. It is useful to differentiate between capability and capacity. Capacity can be considered the resource level that is available at any given moment to achieve an objective. Capability is that mix of skills and competencies possessed by the people in the organization which is needed to achieve the task. The right number of people may not, at a particular juncture, have the right skills. However, when they do, it can be said that both capacity and capability are present. Boisot, (2003) states that, "we shall use the term capability to depict a strategic skill in the application and integration of competencies'. This idea was seen by a school leader as: 'the ability to work at challenges together to bring skills of other people to bear so the organization can learn to solve problems and not just rely on simplistic external solutions'. (Davies \& Davies, B.J, 2006).

The leadership challenge of when to make a significant strategic change is as critical to success as choosing what strategic change to make. The issue of timing can rest on leadership intuition (Parikh, 1994) as much as on rational analysis. When individuals in the organization are ready for change, when the organization needs the change and when the external constraints and conditions force the change, all have to be balanced one against the other. Such judgment is manifested in not only knowing what and knowing how but also knowing when (Boal \& Hooijberg, 2001)as important, knowing what not to do (Kaplan \& Norton, 2001). Therefore we could add to this list knowing what to give up or abandon in order to create capacity to undertake the new activity. Several of the school leaders in the study talked about the critical issue of strategic timing, of getting the time right for change for themselves and others in the school. School leaders also talked about this timing being intuitive (Davies, B \& Davies, B.J., 2006). If the strategic timing is wrong it can have devastating effects on the school. People will be divided, and realizing the strategy will therefore be impossible. In addition to the critical skill of strategic timing is that of strategic abandonment. If a school adopts a new way of doing things or adopts a new strategic priority, how that fits into an already crowded agenda has to be considered. Sometimes this strategies have been abandoned as they did not tie into the current impacting factors. This may result in the institution abandoning the current strategy for the more likely one which will be in tune with the emerging concerns.

\section{Developing Strategic Capabilities}

Strategic capability can be defined as the resources and competences of an organization need to survive and prosper. Prahalad \& Hamel(1990) use the term 'core competencies' whileStalk, Evans, \& Schulman (1992)use the term 'strategic capabilities'. Davies \& Davies (2006) The strategic capabilities are divided into 
two categories; threshold capabilities and capabilities for competitive advantage which are comprised of unique resources and core competencies, both difficult to imitate for competitors Johnson, Scholes and Whittington., (2009) identify strategic capabilities are those resources and competences capabilities needed by an organization to meet minimum customer requirements and for it survival or they could be the threshold competences required to deploy resources so as to meet customers' requirements and support particular strategies.

To survive and prosper an organization needs to understand the challenges of the environment that it faces. It should be clear the capable of delivering in terms of the critical success factors that arise from demands and needs of its customers. The strategic capability to do so is dependent on the resources and the competences it has. These must reach a threshold level in order for the organization to survive. Additionally the organization should be capable of achieving competitive advantage, this requires it to have strategic capabilities that its competitors find difficult to imitate or obtain, it could be in form of a resource or core competences of the organization (The strategic position: strategic capabilities, 2007)

\section{Objective of the Study}

To determine the impact of strategic leadership style on academic performance of the National schools in Kenya.

\section{Methodology}

The study used descriptive research design. A population is the complete group of entities that will be examined in the study (Zikmunnd, Babin, Carr, \& Griffin, 2013). The target population is examined using the units of observation and units of analysis. The unit of observation refers to the units in which the information is received and statistics are compiled or an object about which information is collected (Cooper \& Schindler, 2003). The unit of observation has also been defined as the identifiable organizations or physical entities which are able to report data about their activities (Mugenda, 2003). The unit of observation for this study was the national secondary schools deputies or department heads in Kenya in the 103 national schools. According to the Ministry of Education (2017), there are 103 national schools within the country. The total number of students in these national schools is approximately 107388. The national schools are represented in every county thus the information gathered would be representing the country. To ensure that the results acquired were not influenced by aspects of differentiation of the schools in entities such as cognitive ability of the students, infrastructure, government funding a choice to use institutions that are somewhat at par in resources was reached. This ensured that neither of the schools had an added advantage in relation to resources. The sample size of this study was 93 principals of national secondary schools that were drawn using census sampling. Therefore, 93 questionnaires were distributed to the respondents of which only 87 questionnaires were returned making a response rate of 93\%. The six unreturned questionnaires were attributed to unwillingness amongst some principals to participate in the study. This is despite the issuance of a consent letter indicating that (i) the study is meant for an academic purpose only, (ii) maintenance of anonymity in their responses, and (iii) promise of keeping their information confidential. This response rate was deemed sufficient for study. This is because Sekaran \& Bougie, (2011) indicates that a response rate of over $85 \%$ being excellent, $70-85 \%$ very good, $60-70 \%$ acceptable and below $50 \%$ not acceptable.

\section{Findings And Discussions}

\section{Frequency Distribution of Strategic Leadership Style}

In respect to the national school having a formal procedure of evaluating the school principal, a majority of $59.8 \%$ of the respondents strongly agreed on the metric. A cumulative percentage of $100 \%$ were in agreement that their schools observed ethics right from the staff members to the students. In relations to the monitoring of ethical behavior, a majority of $70.1 \%$ of the respondents strongly agreed that they monitored their staff and students to ensure ethical behavior. In respect to the gathering and analysis of relevant data and information for our strategic planning process, $2.3 \%, 48.3 \%$, and $49.4 \%$ of the respondents were neutral, agreed and strongly agreed respectively in relations to the metric.

Table 1: Frequency Distribution of Strategic Leadership Style

\begin{tabular}{|c|c|c|c|c|c|}
\hline & SD & D & $\mathbf{N}$ & $\mathbf{A}$ & SA \\
\hline & $\begin{array}{c}\text { Freq. } \\
(\%)\end{array}$ & $\begin{array}{c}\text { Freq. } \\
(\%)\end{array}$ & $\begin{array}{c}\text { Freq. } \\
(\%)\end{array}$ & $\begin{array}{c}\text { Freq. } \\
(\%)\end{array}$ & $\begin{array}{c}\text { Freq. } \\
(\%)\end{array}$ \\
\hline \multirow{2}{*}{$\begin{array}{l}\text { We have a formal procedure to evaluate The School } \\
\text { principal }\end{array}$} & 0 & 0 & 1 & 34 & 52 \\
\hline & $0.00 \%$ & $0.00 \%$ & $1.10 \%$ & $39.10 \%$ & $59.80 \%$ \\
\hline \multirow{2}{*}{$\begin{array}{l}\text { We ensure ethical behavior in all our students, faculty } \\
\text { and staff }\end{array}$} & 0 & 0 & 0 & 32 & 55 \\
\hline & $0.00 \%$ & $0.00 \%$ & $0.00 \%$ & $36.80 \%$ & $63.20 \%$ \\
\hline \multirow{2}{*}{$\begin{array}{l}\text { We have established clear measures to monitor ethical } \\
\text { behavior of students, faculty and staff }\end{array}$} & 0 & 0 & 0 & 26 & 61 \\
\hline & $0.00 \%$ & $0.00 \%$ & $0.00 \%$ & $29.90 \%$ & $70.10 \%$ \\
\hline We gather and analyze relevant data and information for & 0 & 0 & 2 & 42 & 43 \\
\hline
\end{tabular}




\begin{tabular}{|c|c|c|c|c|c|}
\hline our strategic planning process & $0.00 \%$ & $0.00 \%$ & $2.30 \%$ & $48.30 \%$ & $49.40 \%$ \\
\hline \multirow{2}{*}{$\begin{array}{l}\text { We take a long-term view when planning for our } \\
\text { organization's future opportunities and directions }\end{array}$} & 0 & 0 & 0 & 42 & 45 \\
\hline & $0.00 \%$ & $0.00 \%$ & $0.00 \%$ & $48.30 \%$ & $51.70 \%$ \\
\hline \multirow{2}{*}{$\begin{array}{l}\text { We specify timetables for accomplishing our strategic } \\
\text { objectives }\end{array}$} & 0 & 0 & 1 & 41 & 45 \\
\hline & $0.00 \%$ & $0.00 \%$ & 1.1 & $47.10 \%$ & $1.70 \%$ \\
\hline \multirow{2}{*}{$\begin{array}{l}\text { Our strategic objectives are aimed at developing a } \\
\text { competitive leadership position in our educational } \\
\text { offerings }\end{array}$} & 0 & 0 & 1 & 46 & 40 \\
\hline & $0.00 \%$ & $0.00 \%$ & $1.10 \%$ & $52.90 \%$ & $46.00 \%$ \\
\hline \multirow{2}{*}{$\begin{array}{l}\text { Our strategic objectives address both short- and long- } \\
\text { term challenges and opportunities }\end{array}$} & 0 & 0 & 0 & 39 & 48 \\
\hline & $0.00 \%$ & $0.00 \%$ & $0.00 \%$ & $44.80 \%$ & $55.20 \%$ \\
\hline \multirow{2}{*}{$\begin{array}{l}\text { We convert our strategic objectives into short- and long- } \\
\text { term action plans to accomplish the objectives }\end{array}$} & 0 & 0 & 0 & 41 & 46 \\
\hline & $0.00 \%$ & $0.00 \%$ & $0.00 \%$ & $47.10 \%$ & $52.90 \%$ \\
\hline \multirow{2}{*}{$\begin{array}{l}\text { Strategic plans are translated into specific requirements } \\
\text { for each work unit or department }\end{array}$} & 0 & 0 & 0 & 34 & 53 \\
\hline & $0.00 \%$ & $0.00 \%$ & $0.00 \%$ & $39.10 \%$ & $60.90 \%$ \\
\hline \multirow[t]{2}{*}{ Improvement plans are regularly upgraded } & 0 & 0 & 0 & 30 & 57 \\
\hline & $0.00 \%$ & $0.00 \%$ & $0.00 \%$ & $-34.50 \%$ & $-65.50 \%$ \\
\hline
\end{tabular}

All the respondents agreed to consider the long-term when laying down their strategies. The same was observed when $98 \%$ of the respondents agreed to their principals using timetables with only $1.1 \%$ of being neutral. On the other hand, a majority of $52.9 \%$ of the respondents were agreed that their school's objectives are aimed at ensuring competitive leadership while $46.0 \%$ of the respondents strongly agreed with the metric. The aspect of creation of competitive leadership is of importance to the academic performance of the school. These results are compared to Litz, Juma, \& Carroll (2016) study in Greece secondary schools that indicated the importance of competitive leadership. Amongst the competitive aspects of leadership that the study identified include creation of conducive school climate, school leadership, personnel management, administration and school management, student management, and relationships with parents and the community but that they desired to improve with regard to curriculum development and professional and in-service development.A 100\% of the respondents were affirmative that their schools' strategies were geared at ensuring that both long-term and short term challenges and opportunities are met. In relations to the school breaking down, long-term strategies into smaller short term goals, $47.1 \%$ and $52.9 \%$ of the respondents agreed and strongly agreed respectively. All the respondents (100\%) were affirmative that their schools and management in general define the work requirements for each department and work unit in their schools. A majority of $60.9 \%$ of the respondents strongly agreed that Strategic plans were translated into specific requirements for each work unit or department. Finally, a cumulative percentage of $100 \%$ indicated that in their school the improvement plans were regularly upgraded and stakeholders had loyalty.

\section{Means and of Strategic Leadership Styles}

The means and the standard deviations of strategic leadership styles were examined using a five point likert scale with descriptors Strongly Disagree (SD), Disagree (D), Uncertain (U), Agree (A) and Strongly Agree (SA). These were represented as 1,2,3,4 and 5 respectively in the SPSS input spread sheet.

Table 2: Means and Standard Deviations of Strategic Leadership Styles

\begin{tabular}{|c|c|c|c|c|c|}
\hline & & Mean & $\begin{array}{l}\text { Respondents } \\
\text { on average } \\
\text { tended to; }\end{array}$ & $\begin{array}{l}\text { Std. } \\
\text { Dev. }\end{array}$ & $\begin{array}{l}\text { Responses } \\
\text { Distributed } \\
\text { around the mean; }\end{array}$ \\
\hline $\begin{array}{l}\text { We have a formal procedure to evaluate The School } \\
\text { principal }\end{array}$ & 87 & 4.5862 & Strongly Agree & 0.51831 & Moderately \\
\hline $\begin{array}{l}\text { We ensure ethical behavior in all our students, faculty } \\
\text { and staff }\end{array}$ & 87 & 4.6322 & Strongly Agree & 0.48501 & Closely \\
\hline $\begin{array}{l}\text { We have established clear measures to monitor ethical } \\
\text { behavior of students, faculty and staff }\end{array}$ & 87 & 4.7011 & Strongly Agree & 0.46041 & Closely \\
\hline $\begin{array}{l}\text { We gather and analyze relevant data and information for } \\
\text { our strategic planning process }\end{array}$ & 87 & 4.4713 & Agree & 0.54643 & Moderately \\
\hline $\begin{array}{l}\text { We take a long-term view when planning for our } \\
\text { organization's future opportunities and directions }\end{array}$ & 87 & 4.5172 & Strongly Agree & 0.5026 & Moderately \\
\hline $\begin{array}{l}\text { We specify timetables for accomplishing our strategic } \\
\text { objectives }\end{array}$ & 87 & 4.5057 & Strongly Agree & 0.52548 & Moderately \\
\hline $\begin{array}{l}\text { Our strategic objectives are aimed at developing a } \\
\text { competitive leadership position in our educational } \\
\text { offerings }\end{array}$ & 87 & 4.4483 & Agree & 0.52293 & Moderately \\
\hline $\begin{array}{l}\text { Our strategic objectives address both short- and long- } \\
\text { term challenges and opportunities }\end{array}$ & 87 & 4.5517 & Strongly Agree & 0.5002 & Moderately \\
\hline $\begin{array}{l}\text { We convert our strategic objectives into short- and long- } \\
\text { term action plans to accomplish the objectives }\end{array}$ & 87 & 4.5287 & Strongly Agree & 0.50207 & Moderately \\
\hline $\begin{array}{l}\text { Strategic plans are translated into specific requirements } \\
\text { for each work unit or department }\end{array}$ & 87 & 4.6092 & Strongly Agree & 0.49076 & Closely \\
\hline Improvement plans are regularly upgraded & 87 & 4.6552 & Strongly Agree & 0.47807 & Closely \\
\hline
\end{tabular}


The interpretation of the scores $1<\mu<1.5,1.5<\mu<2.5,2.5<\mu<3.5,3.5<\mu<4.5$, and $4.5<\mu \leq 5$ where $\mu$ represents the mean were that the respondents on average tended to strongly disagree, disagree, be uncertain, agree and strongly agree respectively in relations to the given metric. On the other hand, the standard deviation interpretation with the scores $0<\sigma \mathrm{X}<0.5,0.5<\sigma \mathrm{X}<1$, and $\sigma \mathrm{X} \geq 1$ implied that the responses were concentrated around the mean (high consensus), responses were moderately distributed, and there was no consensus on the given metric respectively. All the responses of the strategic leadership style were moderately distributed since they had a standard deviation between 0.5 and 1.0 except on four metrics. These five metrics included; We ensure ethical behavior in all our students, faculty and staff; We have established clear measures to monitor ethical behavior of students, faculty and staff; Strategic plans are translated into specific requirements for each work unit or department, and Improvement plans are regularly upgraded which standard deviations of less than 0.5 signifying that the responses were closely distributed around the mean and hence high consensus.

\section{Multiple Linear Regression of Strategic Leadership Style}

The cumulative effect of strategic leadership styles on the academic performance was examined using multiple linear regression analysis. The positive multiple correlation coefficient $(\mathrm{R})$ indicated the cumulative effect of strategic leadership strategic leadership is positively correlated to academic performance of national schools. There is a strong and positive correlation of 0.524 between the strategic leadership styles and academic performance of national schools. On the other hand, the coefficient of determination (R Square) of 0.274 indicates that $27.4 \%$ of the variance in academic performance can be attributed to strategic leadership styles in national schools.

Table 3: Model Summary of Strategic Leadership Styles

\begin{tabular}{|c|c|c|c|c|}
\hline Model & R & R Square & Adjusted R Square & Std. Error of the Estimate \\
\hline 1 & $.524^{\mathrm{a}}$ & 0.274 & 0.04 & 1.52241 \\
\hline a. & Predictors: (Constant), Strategic Leadership Styles & \\
\hline
\end{tabular}

To examine if the multiple linear regression was a good fit for data, then the ANOVA of strategic leadership styles was examined. Since $F(21,65)=1.170, p>0.05$ then the model was considered not a good predictor of academic performance as a $\mathrm{p}$ value of 0.307 , implied a $30.7 \%$ likelihood of a multiple linear regression model giving the wrong responses. Therefore, the multiple linear regressions of strategic leadership styles was not undertaken.

Table 4: ANOVA of Strategic Leadership Styles

\begin{tabular}{|l|l|c|c|c|c|c|}
\hline \multicolumn{2}{|c|}{ Model } & Sum of Squares & df & Mean Square & F & Sig. \\
\hline \multirow{4}{*}{1} & Regression & 56.937 & 21 & 2.711 & 1.17 & $.307^{\mathrm{b}}$ \\
\cline { 2 - 7 } & Residual & 150.652 & 65 & 2.318 & & \\
\cline { 2 - 7 } & Total & 207.588 & 86 & & & \\
\hline
\end{tabular}

\section{Recommendation}

The study recommended that the national schools should emphasize the role of strategy leadership styles with view of improving on the academic performance of their schools. However strategy leadership styles variables alone cannot influence the academic performance of their schools as strategy leadership styles were found not to have a significant influence on the academic performance with a $\mathrm{P}$ value of 0.307 . This was largely attributed to the fact that the national schools have a set policies and procedures in which leaders are required to adopt hence little variances in terms of leadership styles in various schools and leadership styles for an individual is hence not a key determinant of academic performance in national schools. School should however focus on leadership traits, resource availability and strategy execution plan besides variables of leadership styles.

\section{References}

[1] Ackers, J., \& Hardman, F. (2001). Classroom interaction in Kenya Primary schools. British Association for International and Comparative Education, 31(2) 245-261.

[2] Adair, J. (2002). Effective Strategic Leadership. London: Macmillan.

[3] Advance Business Consulting . (2015, 6 29). http://www.advancebusinessconsulting.com/. Retrieved from Advance Businesss Consulting : http://www.advancebusinessconsulting.com/advance!/strategic-alignment.aspx

[4] Alchian A, D. H. (1972). Production, Information cost and economic organization. American Economic Review, 777-95.

[5] Altschuld, J. W. (1995). Assessing the effectiveness of research organizations. Evaluation Review, 197-216. Retrieved from http://dx.doi.org/10.1177/0193841X9501900205

[6] Amos T. (2007). Strategic Leadership: Key driver for strategic implementation. Management Today.

[7] Andolsen. A.A. (2007). Strategic Alignment ? ARMA International.

[8] Ansoff L. (1965). Corporate Strategy. New York: McGraw Hill.

DOI: $10.9790 / 487 X-1907010924 \quad$ www.iosrjournals.org 18 | Page 
[9] Ashraf, G. K. (2012). A Review of Models of Organization Effectiveness: A look at Cameron's Model in Higher Education. International Education Studies Vol 5, 2.

[10] Avison, D. J. (2004). Using and Validating the strategic alignment model . Journal of Strategic Information Systems 13, $223-246$.

[11] Avison.D., J. J. (2004). Using and Validating the strategic alignment model. Journal of Strategic Information Systems , 13:223-246.

[12] Avolio, B., Bass, B., \& Jung, D. (1978). Re-Examining the componenets of tranformational and transactional leadership using the multifactor leadership questionaire. Journal of Occupational and Organizational Psychology; 72, 441-462.

[13] Avolio, B., Bass, B., \& Jung, D. (1999). Re-examining the componenets of transformational and transactional leadership using the multifactor leadership questionnaire. Journal of Occupational and Organizational Psychology 72, 441-462.

[14] Bain J.S. (1968). Indurstrial Organization. New York: John Wiley.

[15] Barnett, V. (2002). Guide to Statistical Information: Sampling for surveys. The Higher Education Academy : Maths Stats\& or Network.

[16] Barney J, A. A. (2001). The Resource Based View: Origins and Implications, Handbook of Strategic management. Oxford, UK: Blackwell Publishers.

[17] Barney, J. (1991). Furm Resources and sustained competitive advantage. Journal of Management, Vol.17 No.1, 99-120.

[18] Bass B. (1985). Leadership and Perfomance beyond Expectation. New York: The Free Press.

[19] Bass B.M. (1998). Transformational Leadership: Indurstry, Military and Educational Impact . Mahwah, NJ: Erlbaum.

[20] Bass B.M. (2009). Handbook of Leadership: Theory, Research and Managerial Applications. New York: Free Press.

[21] Bass, B. (2007). Executive and Strategic Leadership. Internation Journal of Business.

[22] Beare, H. (2001). Creating the future school. London, RoutledgeFalmer.

[23] Bell, L. (2002). Strategic Planning and School Management: Full of Sound and Fury, Signifying nothing? Journal of Education Administration 40(5), 407-424.

[24] Bennet, D. (2000). The school of the future, National College for school Leadership. Nottingham, NCSL: Leadership Evidence Base.

[25] Bianco, T., \& Schermerhorn, J. (2006). Self- Regulations, Strategic Leadership and Paradox in Organization Change. Journal of Organizational Change Management 19 (4), 457-475.

[26] Blazey, M. (2009). Insights to performance excellence: An Inside look at the 2009-2010 Baldrige Award Criteria. Milwaukee, Wisconsin: ASQ Quality Press.

[27] Boal, K. \&. (2001). Strategic Leadership Research. Leadership Quarterly, 11(4), 515-549.

[28] Boal, K., \& Hooijberg, R. (2001). Strategic Leadership Research. Moving On. Leadership Quarterly, 515-549.

[29] Boisot, M. (2003). 'Preparing for turbulence. In B. Garratt, Developing Stategic Thought. London: McGraw-Hhill.

[30] Brecken, D. (2004). Leadership Vision and Strategic Direction. The Quality Management Forum, Volume 30 (1), 6-7.

[31] Bridoux, F. (n.d.). A Resource Based Approach to Perfomance and Competition: An overview of the connenction between resources and competition. Institit d' Administration et de Gestion, Universite' Catholique de Louvain. Belgium.

[32] Burns J.M. (1978). Leadership. New York: Harper and Row.

[33] Business/IT- Alignment. (2015, June 30). https://businessitalignment.wordpress.com/2010/12/22/strategic-alignment-maturitymodel-luftman/. Retrieved from Business/ IT- Alignment: https://businessitalignment.wordpress.com/2010/12/22/strategicalignment-maturity-model-luftman/

[34] Cameron, K. (1981). Domains of organization effectiveness in colleges and universities. Academy of Management Journal, 24, 2547.

[35] Cameron, K. (1981). Domains of Organizational Effectiveness in institutions of higher education. Retrieved from Academy of Management Journal 24 (1): http://dx.doi.org/10.2307/255822

[36] Cannella Jr, A. (2001, August). Upper echelons: Donald Hambrick on executives and strategy.

[37] Cannella, A., \& Monroe, M. (1997). Contrasting perspectives on strategic leaders: Toward a more realistic view of top managers. Journal of management, 23, 213-238.

[38] Carpenter, M., Geletkanycz, M., \& Sanders, W. (2004). Upper Echelons Research Revisted: Antecedents, Elements and Consequence of Top Management Team Composition. Journal of Management 30(6), 749-778.

[39] Chandler A.Jr. (1962). Strategy and Structure: Chapters in the History of American Indurstrial Enterprise. Cambridge. MA: The MIT Press.

[40] Chandler. A.D. (1962). Strategy and Structure: Chapters in the History of the American Entreprise. Cambridge, M.A: The MIT Press.

[41] Cheng, Y. (2000). Strategic Leadership for Educational Transformation in the New Millennium. Chulalongkorn Educational Review 6 (2), 15-32.

[42] Chorn, N. (1991). The "alignment" theory: Creating strategic fit. Management Decision, 20-26.

[43] Chorn. H.N. (1991). The " Alignment" Theory: Creating strategic fit. Management Decision, 20.

[44] Chrispeels, j., Burke, P., Johnson, p., \& Daly, A. (2008). Aligning mental models of district and school leadership teams for reform coherence. . Journal of Case in Educational Leadership, (11)1-10, . doi: 10.1177/1555458908324903.

[45] Ciborra, C. (1997). De Profudis? Deconstructing the concept of strategic alignment. https://www.informatik.gu.se/conference/iris20/60.html.

[46] Ciulla, J. (1998). Ethics, the heart of Leadership. Westport: CT: Quorum.

[47] Cobb, A., \& Wry, T. (2014). Resource- Dependence Theory. Oxford Bibliographies, 10.1093/OBO/9780199846740-0072.

[48] Cohen, W., \& Levinthal, D. (1990). Absorptive Capacity: A new perspective on learning and innovation. Administration Science Quarterly, 35, 128-152.

[49] Col Guillot, M. (2003). Strategic Leadership; Defining the challenge,. Air \&Space Power Journal, 65-75.

[50] Compton, S. (2008). High Reliability Leadership: Developing Executive Leaders for High reliability organizations. Faculty of School of Business of the George Washington University.

[51] Cooper, R., \& Schindler, P. (2014). Business Research Methods (12th Ed.). New York: Mc-Graw-Hill Publishers.

[52] Cyert R.M \& March J.G. (1963). A Behavioural Theory of the firm. Englewood Cliffs, NJ: Prentice- Hall.

[53] D' Souza, S. (n.d.)

[54] Dalton, T. \&. (1988). The politics of measuring public sector performance: Promoting Productivity in the public sector. Macmillan.

[55] Darmody, M., \& Smyth, E. (2016). Primary Schools Principals' Job Satisfaction and occupational stress. International journalo of icational management vol.30 Issue 1, 115-128.

[56] Davies, B. (2005). The Essentials of School Leadership,. London: Crown Press.

[57] Davies, B. (2015, 7 2). success and sustainability : Developing the strategically- focused school. Retrieved from http://www.brentdavies.co.uk/: http://www.brentdavies.co.uk/Web\%20Articles/NCSL\%20 \%20Strategy.pdf 
[58] Davies, B., \& Davies, B. (2004). Strategic Leadership. School Leadership \& Managent, 29-30.

[59] Davies, B., Davies, B., \& Ellison, L. (2015, September 9). www.brentdavies.co.uk. Retrieved from http://www.brentdavies.co.uk/Web\%20Articles/NCSL\%20 \%20Strategy.pdf: http://www.brentdavies.co.uk/Web\%20Articles/NCSL\%20 \%20Strategy.pdf

[60] Davis, R., \& Mukamal, K. (2006). Hypothesis Testing Means. Statistical Primer for Cardiovascular Research, 1078-1082.

[61] Davs, F., \& Cobb, J. (2009). Resource Dependence Theory: Past and Future. Research in Sociology of Organizations.

[62] Day, R. (1979). How to write and publish a scientific paper. Phillladelphia: ISI press.

[63] Deeboonme, W., \& Ariratana, W. (2014). Relationship Between strategic Leadership and School Effectiveness. International Conference on Education \& Educational Psychology (pp. 982-985). Procedia - Social and Behavioral Sciences 112.

[64] Diefenbaeh, T., \& Silince, J. (2011). Formal and Infromal Hierachy in Different Types of Organization. Organizational Studies , 32(11);1515-1537.

[65] Dierendonck D.V. (2011). Servant Leadership: A review and synthesis. Journal of Instruction

[66] Dr. Almansour, Y. (2012). The Relationship Between Leadership Styles and Motivation of Managers Concceptual framework. Journal of Arts, Science and Commerce.

[67] Draft, R. (2011). The Leadership Experience (5th Edition ed.). Cincinnati, Ohio: Engage Learning South- Western.

[68] Draft, R. (2011). The Leadership Experience (5th Edition ed.). Cincinnati, Ohio: Engage Learning South- Western.

[69] Drucker P.F. (2002). Innovation and Entrepreneurship. Oxford: Butterworth-Heinemann.

[70] D'Souza., \& Dr. Sequeira, A. (n.d.). Application of Malcolm Baldrige Quality framework to enhance pefromance in healthcare organization. https://ssrn.com/abstract=2037944.

[71] Duursema, H. (2013, March 15). Strategic Leadership. Moving beyond the Leader - Follower Dyad. Strategic Leadership. Moving beyond the Leader - Follower Dyad. Duursema Hester.

[72] Eacott, S. (2011). New Look Leaders or a New Look at Leadership? . International Journal of Educational Management (25)2, 134143.

[73] Edmonds, R. (1979). Effective schools for the urban poor. Educational Leadership 37 (1), 15-27.

[74] Ercetin, S., \& Maya, I. (2010). A Ke concept in effective school development: Strategic Leadership. 2nd Internation Symposium on sustainable development , 212-215.

[75] Essens, P. B. (2005). Military Command Team Effectiveness: Model and Instrument for Assessment and Improvement. NATO RTO technical report.

[76] Essens, P. J. (2009). Team Effectiveness in Complex Settings: Cross-Disciplinary Perspectives and Approaches. New York/ Hove: Taylor and Francis Group.

[77] Evans, R., \& Lindsay, M. (2008). Managing for Quality and Performance Excellence. Mason, OH: South- Western: Cengage Learning.

[78] Fadare, S. (2013). Resource Dependency Imstitutional and stakeholder organizational theories in France, Nigerial and India. International Journal of Management and Sustainability 2(12), 231-236.

[79] Fielder, F. (1964). A contigency Model of Leadership Effectiveness. Advances in Experimental Social Pyschology, 149-190

[80] Finkelstein, S., \& Hambrick, D. (1996). Strategic Leasership: Top executive and their effect on organizations. Minneapolis/ St. Paul . MN: West.

[81] Finkelstein, S., Hambrick, D., \& Cannella Jr, A. (2009). Strategic Leadership. Theory and Research on Executite Top Management Teams and Boards. New York: Oxford Univeristy Press.

[82] Finkelstein, S., Hambrick, D., \& Cannella Jr, A. (2009). Strategic Leadership. Theory and Research on Executives , Top Management Teams and Boards. 198 Madison Avenue, New York, New York 10016: Oxford University Press.

[83] Flick, U. (2009). An Introduction to qualitative research. Sage Publications.

[84] Foma, E. (2012). Talking of Malcolm Baldrige National Quality Award. Review of Interactive Business \& Econimic Research, 223233.

[85] Freedman, M. \& Tregoe, B. (2003). The Art and Discipline of Strategic Leadership. New York: MCGraw- Hill.

[86] Fuchs, H. M. (2000). Strategic integration: Competing in the age of capabilities. California Management Review, Vol 42 No.3.

[87] Fuchs. H.P., M. M. (2000). Strategic Integration: Competing in the age of capabilities. California Management Review, 42(3) 118147.

[88] Fullan, M. (2004). Leadership and Sustainability : System Thinkers in Action . Thousand Oaks. C.A.: Sage Publications.

[89] Gakenia, C. (2016). Strategic Leadership alignment on Academic performance: Focus on National High schools in Kenya.

[90] Gamage, D. (2006). Proffessional Development for Leaders and Managers of self governing schools. Dordrecht: Springer.

[91] Garbarine, S., \& Holland, J. (2009). Quantitative and Qualitative Methods in Impact Evaluationa nd Measuring Results. Governance and Social Development Resource Centre.

[92] Gardner, H. (1985). The mind's new science: a history of the cognitive revolution. New York: Basic Books.

[93] Geiser, S., \& Santelices, M. (2007). Validity of High School Grades in Predicting Students Success Beyond the Freshman Year. Research \& Occasional Paper Series : CSHE. 6.07.

[94] Gernert, D. (2011). The Organisation as an obstacle to creativity. International Journal of Applied Systemic studies , 4(1): 126-135.

[95] Githua, B., \& Nyabwa, R. (2008). Effects of Advance organizer strategy during instruction on secondary school students mathematics achievement in Kenya's Nakuru district . International journal of science and mathematics education , 6(3) 439-457.

[96] Goddard, I. a. (1993). Managing Staff in Schools . Oxford Heinmann Educational

[97] Goddard, R., Hoy, W., \& Hoy, A. (2000). Collective teacher efficacy: Its meaning, measure, and impact on student achievement American Educational Research Journal. 37(2), 479-507.

[98] Goldberger, S., Keough, R., \& Almeida, C. (2000). Benchmarks for success in High School Education. Putting data to work in school to career education reform. Boston. Massachusets: LAB at Brown University.

[99] Goodson R.J, M. G. (2009). Situation Leadership Theory. A Test of Leadership Prescriptions . Group \& Organization Management, 446-461.

[100] Government of Kenya. (2012, October 19). The Kenya National Examination Council Act .

[101] Graddy, K., \& Stevens, M. (2005). The Impact of School Resources on Students Performance: A study of private schools in the United Kingdom. ILRL Review, 435-451.

[102] Graen, G. \&. (1975). A role Making Model of Leadrship in formal Organizations: A development Approach. Kent: Ohio: Kent State University Press.

[103] Graen, G. U.-B. (1998). Relationship- Based Approach to Leadership: Development of Leader- Member Exchange (LMX) Theoriy of Leadership of 25 Years:. Greenwich CT.: Jai Press.

[104] Graen, G., \& Scandura, T. (1987). Toward a psychlogy of dyadic organizing. Research in Organizational Behaviour: 9, 175-208. 
[105] Granite State Quality Council. (n.d.). The Malcolm Baldrige Criteria for Performance Excellence. Retrieved from file:///C:/Users/user/Downloads/The\%20Malcolm\%20Baldrige\%20Criteria\%20for\%20Performance\%20Excellence\%20200910.pdf

[106] Gratton, L. (2000). Living Strategy: Putting people at the heart of cororate purpose. London: Financial Times Prentice Hall.

[107] Gratton, L. (2000). Living Strategy: Putting People at the Heart of Corporate Purpose. London: Financial Times Prentice Hall.

[108] Greenleaf R.K. (1977). Servant Leadership. Mahwah: NJ: Paulist Press.

[109] Greenwald, R., Hedges, L., \& Laine, R. (1996). The Effect of School Resources on Student Achievement. Review of Educational Research, , 361-396.

[110] Grix, J. (2010). The foundations of reseach. London: Palgave Macmillan.

[111] Guba, E., \& Lincoln, Y. (1996). Competing Paradigms in Qualitative Reseach. In Denzin \& Lincoln ( Eds.), Handbook of Qualitative Research . USA : Sage Publishers.

[112] Guillot, W. (2003). Strategic Leadership: Defining the challenge. Air \& Space. Power Journal- Winter.

[113] Gupta, J. N. (2009). The Handbook of Research On Entreprise Systems. Hershey, Newyork: Information Science Reference.

[114] Hagen, A., Hassan, M., \& Amin, S. (1998). Criticial Strategic Leadership Components: an empirical investigagtion . SAM Advanced Management Journal, 63(3), 39-44.

[115] Hallinger, p., \& Heck, R. (1996). Reassessing the principal's role in school effectiveness: A review of empirical research 19801995. Educational Administration, Quarterly 32 (1), 5-44.

[116] Hambrick, D. (n.d.). u.

[117] Hambrick, D., \& Finkelstein, S. (1987). Managerial Discretion : A bridge between popular views of organizations. In L. Cummings, \& B. (. Straw, Research In Organizatonal Behaviour ( Vol 9) (pp. 396-406). Greenwich. CT: JAI Press.

[118] Hambrick, D., \& Mason, P. (1984). Upper Echelopns: Donald Hambrick on executive and strategy. Academy of Management Review, 9, 193-206.

[119] Hambrick, D., \& Pettigrew, A. (2001). Upper Echelons: Donald Hambrick on Executives and Strategy. Academy of Management Executives, 15 (3): , 36-44.

[120] Hammonds, K. (2001). Michael Porter's big Ideas. Fast Company, 44, 150-156.

[121] Handerson J.C. (1990). Plugging into strategic partnerships: The critical IS connection. . MIT Sloan Management Review 31 (3), 12-18.

[122] Hannah, S. A. (2008). Leadership efficacy: review and future directions. The Leadership Quarterly, (19), 669-692.

[123] Hatch, M. (1997). Organization Theory: Modern, Symbolic and Postmodern perspectives. Oxford: Oxford University Press.

[124] Hayat, K., Hussain, S., \& Sardar, S. (n.d.). Summary and Analysis Stephen R. Covey's the 8th Habit: From effectiveness to Greatness. Abasyn Journal of Social Sciences. Vol:8 Issue 1, 184-197.

[125] Head Quarters Department of the Army . (2015, June 30). FM 6-22 Leadership Development. Washington, DC, Washington DC, USA.

[126] Henderson, J., \& Venkatramen, N. (1992). Strategic Alignment:A model for organizational Transformational.

[127] Henn, M., Weinstein, M., \& Foard, N. (2006). A Short Introduction to social research. London: Sage.

[128] Hersey, P. B. (1969). Management of Organizational Behaviour: Utilizing Human Behaviour. Englewood Cliff: NJ: Prentice- Hall.

[129] Hitt, L., Wu, D., \& Zhou, X. (2002). Investment in Enterprise resource planning: Business Impact and productivity measures. Journal of Management Information Systems, 19, 71-98.

[130] Hitt, M., Ireland, R., \& Hoskisson, R. (2007). Strategic Management: Competitiveness and globalization (7th ed.). Mason, Ohio: Thomson/ South Western.

[131] Hitt, M., Ireland, R., \& Hoskisson, R. (2011). Strategic Management Competitiveness \& Globalization. Mason, OH: SOUTHWESTERN CENTAGE Learning.

[132] Hoffer, C., \& Schendel, D. (1978). Strategy formulation: Analytical concepts. St. Paul MN: West.

[133] Hoskisson, R., Hitt, M., \& Ireland, R. (2004). Strategic Leadership. In Competing for Advantage. South Western: Thompson.

[134] House R.J \& Aditya R. (1997). The Social Scientific study of Leadership: Quo Vadis? Journal of Management, 23. 409-474.

[135] House, R., \& Aditya, R. .. (1997). The Social Scientific Study of Leadership: Quo Vadis? Journal Of Management, 23, 409-474.

[136] House, R., \& Mitchell, T. (1974). Path-Goal Theory of Leadership. Journal of Contemporary Business, 81-97.

[137] Howell, j., \& Dorfman, p. K. (1986). Moderator Variables in Leadership Research. Academy of Management Review, 11, 88-102.

[138] Hoy, W., \& Miskey, C. (2008). Educational Administration: Theory, research and practise, 8th edition . Boston: McGraw-Hill.

[139] Hrebiniak, L. (2005). Making Strategy Work- Leading effective execution and change. Wharton School Publishing .

[140] Hunt J. G. Dodge G.E. (1997). Leadership Complexity and development of Leaderplex Model. Journal of Management , 23, 375408.

[141] Hunt J.G. (1991). Leadership A new synthesis. Newsbury Park, CA: Sage,.

[142] Hunt J.G. (1999). Transofmration/ Charismatic Leadership's Transformational of the field. An Historical Essay . Leadership Quarterly, 129-144.

[143] Improvement, U. D. (1997). Public and Private Schools: How do they differ. 1-39.

[144] Ireland, R. H. (2005). Achieving and Maintaining strategic competitiveness in the 21st Century: The role of Strategic Leadership. Account of management executive, Vol 19, No. 4.

[145] Jaggi, S. (n.d.). Descriptive Statistics and Explatory Data Analysis.

[146] Johnson G., S. K. (2009). "Fundamentals of Strategy. Pearson Education Limited.

[147] Judge, T., \& Piccolo, R. (2004). Transformation \& Transactional Leadership: A Meta- Analytic test of relative valility. . Journal of Applied Psychology. 89(5), 755-768.

[148] Junarso, T. (2009). Leadership Greatness. Best practises to become a great leader. New York: iUniverste.

[149] Kaplan R.S \& Norton D.P. (2006). Alignment: Using the balance scoreccard to create corporate synergies. Boston: Harvard Business School.

[150] Kaplan, L., Owings, W., \& Nunnery, J. (n.d.). Principal quality: A Virginia study connecting interstate school leaders licencesure consortium standards with student achievement. NAASP Bullentin, 89 (643), 28-44.

[151] Kaplan, R., \& Norton, D. (2001). On balance. CFO, 17, 73-78.

[152] Kaplan, R., \& Norton, P. (2005). The Office of Strategy Management. Havard Business Review, October 2005 Issue.

[153] Keller, R. (2006). Transformational Leadership, initiating structure and substituties for leadership: A longitudinal study of research and development project team performance. Journal of Applied Psychology. 91(1), 202-210.

[154] Kerr, S. J. (1978). Substitutes for Leadership: Their meaning and measurement. Organizational Behaviour and Human Performance , 375-403.

[155] Kerr, S., \& Jemier, J. (1978). Subsitutes for leadership: Their meaning and measurements. Organization Behaviour and Human Performances. 22, 375-403. 
[156] Khadem R. (2008). Alignment and follow-up: steps to strategy execution. Journal of Business Strategy 29(6), 29-35.

[157] Kilmoski, R., \& Zaccaro, J. (2001). The Nature of Organizational Leadership: Understanding the Performance Imperatives Confronting today's leaders . Society for Indurstrial and Organizational Psychology.

[158] Kitonga, D., Bichanga, W., \& Muema, B. (2016). strategic leadership and organization performance in Not for Profit organizations in Nairobi County in Kenya. International Journal of Scientific and Technology Research, Vol.5, 17-27.

[159] Kleijnen, J. D. (2009). Organisational values in higher education: Perceptions and preferences of staff. Quality in Higher Education, 15 (3), 233-249.

[160] Kleijnen, J., Dolmans, D., Muijtjens, A., Willems, J., \& Van Hout, H. (2009). Organisational values in higher education: Perceptions and preferences of staff. Quality in Higher Education,15 (3), 233-249.

[161] Koskei, R., \& Katwalo, A. D. (2013). Analysis of the Influence of Strategic Leadership capability on performance of research insitutions in Kenya. International Journal of Science and Research (IJSR), 1830-1837.

[162] Kruger, M., Witziers, B., \& Sleegers, P. (2007). The impact of school leadership on school level factors: Validation of causal model . School Effectiveness and School Improvement 18 (1), 1-20 doi: 10.1080/09243450600797638.

[163] Kuhn, T. (1962). The structure of scientific revolutions. Chicago IL.: Unversity of Chicago Press, 1962.

[164] Kuznets, N. (n.d.). Using benchmarking measurement to improve performance over time. AAAHC quality improvement strandards.

[165] Labovitz G.H \& Rosansky V. (1997). The Power of Alignment:how great companies stay centred and accomplish extraordinary things. New York: Wiley.

[166] Labovitz, G. (2004). The Power of alignment: how the right tools enhance organisational focus. Business Performance Management , 30-35.

[167] Labovitz, G. a. (1997). The power of alignment: how great companies stay centred and accomplish extraordinary things. New York: Wiley.

[168] Labovitz, G., \& Rosansky, V. (1997). The power of alignment: How great companies centrered and accomplished extraordinary things. New York. NY: John Wiley and Sons.

[169] Lear, L. (2012). The relationship between strategic leadership and strategic alignment in high-performing companies in South Africa.

[170] Lear. W.L. (2012). The relationship between strategic leadership and strategic alignment in high-performing companies in South Africa.

[171] Leithwoo, K., Day, C., Sammons, P., Harris, A., \& Hopkins, D. (2006). Successful School Leadership. What is it and How it Influences Pupil Learning. Nottingham: University of Nottingham.

[172] Leithwood, K., \& Mascall, B. (2008). Collective Leadership effects on student achievement . Educational Administration Quartlerly, 44 (529), 1-34; doi: 10.1177/0013161X08321221.

[173] Leithwood, K., Seashore, K., Anderson, S., \& Wahlstrom, K. (2004). How Leadership Influences student learning. Minnesota: The Wallace Foundation.

[174] Lezotte, L. (2001). Revolutionary and evolutionary: The effective schools movement. Okemos, MI: Effective Schools Products, Ltd.

[175] LI, Z., Gupta, B., Loon, M., \& Casimir, G. (2016). Combinnative aspects of leadership style and emotional intelligence. Leadership and Organization Development Journal Vol. 27 Iss:1 , 107-125.

[176] Liu, B., \& Fu, Z. (2011). Relationship between strategic orientation and organizational performance in Born Global: A Critical Reivew. International Journal of Business and Management, 109-115.

[177] Lord R.G, M. K. (1984). A Test of Leadership Categorization theory: Internal Structure, Information Processing and Leaderhip Perception. Organizational Behavior and Human Performance, 34, 343-378.

[178] Lord, R., \& Moher, K. (1991). Leaderhip and information processing. Boston: Unwin Hyman.

[179] LTC. Tirtan, C. (2011). Organization Culture. The 6th International Scientific Conference.

[180] Luftman, J. (2000). Assesing Business- IT Alignment Maturity. Commnucations of Assosiation for Information Systems, Article 14.

[181] Luftman, J. L. (1996). Transforming the entreprise: The Alignment in Practise. New York: Oxford Press.

[182] Luftman, J. P. (1999). Enablers and Inhibitors of Business- IT Aligment. Communications of the Association for Information Systems, Volume 11.

[183] Lundholm, M., Simsek, Z., Ling, y., \& Veiga, j. (2006). Ambidexterity and Performance in Small - to medium sized firms: The pivotal role of top management team behavioural integration. Journal of Management , 32(5);646-672.

[184] Lundholm, S., Rennstam, J., \& Alvesson, M. (2012). Understanding Hierachy in Contemporary Work. Emarald Group Publising.

[185] Lydia, L., \& Nasongo, J. (2009). Role of the Lead teacher in academic achievement in secondary schools in Vihiga District, Kenya Current Research. Journal of Social Sciences 1(3), 84-92.

[186] Macedo, I., \& Pinho, C. (2006). The relationship between resource dependence and market orientation: The specific case of non-profit organisations. European Journal of Marketing, Vol. 40 Iss: 5/6, pp.533 - 553.

[187] Mackey A. (2008). The Effect of CEO's on organizational Performance. Strategic Management Journal , 1357-1367.

[188] Makgone, S. (2012, November). An evaluation of strategic leadership in selected schools and its contribution to academic perfomance.

[189] Martimore, P. (1998). The Road to Improvement: Reflections on School Effectiveness. Swets \& Zeitlinger Publishers.

[190] Maru, P. (2013). INFLUENCE OF PRINCIPALS 'LEADERSHIP STYLES ON STUDENTS' PERFORMANCE AT KENYA CERTIFICATE . Nairobi.

[191] Mason E. ( 1939). Price and Production Policies of Large Scale Enterprises. Amaerican Economic Review, 61-74.

[192] Mathe, S., \& Dr. Kiiru, G. (2016). Effects of Strategic Leadership on Perfomance of MFI's Kenya. International Journal Of Advancement In Engineering Technology, Management and Applied Science. Vol 03- Issue 11, 114-119.

[193] McDaniel, C., \& Gates, R. (2015). Marketing Research, 10th Ed. Wiley E-Text.

[194] McGrath, G., \& MacMillan, I. (2000). Entrepreneurial Mindset: Strategies for Continously Creating Opportunity in an Age of Uncertainity. Havard Business School Press Books.

[195] Mehra, A., Smith, B., Dixon, A., \& Robertson, B. (2006). Distributed leadership in teams: The network of leadership perceptions and team performance. The Leadership Quarterly, 232-245.

[196] Meindl J.R, S. E. (1985). The Roman of Leadership. Administrative Science Quarterly , 78-102.

[197] Meindl, J. (1993). Reinventing Leadeship: A Radical social psychological apporach in J.K. Murningham (Ed). Englewood, NJ: Prentice Hall.

[198] Mertens, D. (2005). Research Methods in education and psychology: Integrating diversity with quantitative and qualitative approaches. Thousand Oaks: Sage. 
[199] Ministry of Education. (1980). Education Act. Chapter 211. Nairobi: Government Printer

[200] Montgomery, C. (1993). Putting Leadership back into strategy. Havard Business Review. May/ June: 76.

[201] Morgan, G. (1997). Images of Organizations. Thousand Oaks. CA: Sage Publications.

[202] Munir, F., \& Khalil, U. K. (2016). Secondary School Teachers' Perceptions of their Principal's Leadership Behaviours and their academic performance at Secondary School Level. Bulletin of Education and Research, 41-55.

[203] Musungu, L., \& Nasongo, J. (2008). The head-teacher's instructional role in academic achievement in secondary schools in Vihiga district Kenya. Educational Research and Review.

[204] Mutia, P. (2015). Strategic Leadership influence on church growth in Kenya. Retrieved from http://erepo.usiu.ac.ke/: http://erepo.usiu.ac.ke/bitstream/handle/11732/2641/PETER\%20M.\%20MUTIA\%20DBA\%20Thesis\%202016.pdf?sequence=1\&is Allowed=y

[205] Mwamuye, K. (2012). The Role of Leadership in Performance of Primary Schools in Kenya: A Case of Mombasa District. International Journal of Business of Commerce, 21-36.

[206] Narayanan, V., \& Zane, L. (2009). Inventing a future for strategic leadership phenomenal variety and epistemic opportunities. Journal of Strategy and Management, 2(4), 380-404.

[207] National Comprehensive centre for Teacher Quality. (2010). Evaluating school principals

[208] Naver, J., \& Slater, S. (1990). The effect of a market orientation on business profitability. Journal of marketing, 54(4), 20-35.

[209] Nganga, U. (2013). Strategic leadership and performance of manufacturing firms in Kenya.

[210] Nthenya, S. (2015, 10 1). Challenges faced by secondary school headteachers in leadership and management of human resources- in Nzaui district Makueni county- Kenya. Nairobi.

[211] Nthini, E. (2013). Effects of strategic leadership on the performance of commercial and financial state corporations. Retrieved from chss.uonbi.ac.ke/sites: http://chss.uonbi.ac.ke/sites/default/files/chss/Evelyn\%20Katee\%20Nthini-\%20MBA\%20Project_1.pdf

[212] Nueman, W. (2006). Social Research Methods: Qualitative and Quantiative Approaches, 6th Edition . Boston: Pearson Education

[213] Nyamboga, O.T.,; Gwiyo, S.J.,; Dr Njuguna, F.W., ; Dr.Waweru S.N.,; Nyamweya, B.O.,; Gongera, P.G.,. (2014). Journal of Education and Practise, Vol. 5. No 22.

[214] Nyongesa, P. (2014). www.uonbi.ac.ke. Retrieved http://erepository.uonbi.ac.ke/bitstream/handle/11295/77724/Lukingi_Head\%20teacher\%E2\%80\%99s\%20leadership\%20style\%20o n\%20school\%20academic\%20performance $\% 20$ in $\% 20$ Kenyan $\% 20$ secondary $\% 20$ schools.pdf? sequence $=1$.

[215] Obunga, C., Marangu, W., \& Masungo, T. (2015). Strategic Leadership and Performance of Saving and Credit Co-operative societies in Kakamega County, Kenya. European Journal of Business and Management, Vol 7, No.13, 65-75.

[216] Odumeru, J., \& Ifeanyi, G. (2013). Transformational Vs. Transactional Leadership Theories: Evidence in Literature. Internation Review of Managaement and Business Research Vol.2 Issue.2, 355-361.

[217] Okode, G. (2013). Influence of Secondnary Schools Strategic Plannihng on Students Academic Performance in Rachuonyo North District, Kenya. Retrieved from http://erepository.uonbi.ac.ke/: http://erepository.uonbi.ac.ke/bitstream/handle/11295/55797/ABSTRACT.pdf?sequence=3

[218] Orndoff, K. (2002). Developing strategic competencies: a starting point. The information management journal. July- August, 57-52

[219] Pedersen, K. (2008). Cracking the code of Strategy Execution. Copenhagen Business School.

[220] Porter, M. (1996). What is strategy? Harvard Business Review, 61-78.

[221] Prahalad, C., \& Hamel, G. (1990). The core competencies of the corporation. Harvard Business Review,, 68: 79-93

[222] Prof.Scheerens, J. (2013). What is effective schooling. International Baccalaureate Organization.

[223] Pugh, D., \& Hickson, D. (1993). Great writers on organizations: The omnibus edition. Brookfield, VT: Dartmouth Publishing.

[224] Quinn R. E. (1988). Beyond Rational Management . San Francisco, C.A: Jossey- Bass

[225] Quong T. \& Walker A. (2010). Seven Principles of Strategic Leadership. Academia Edu, Volume 38.

[226] Quong, T., \& Walker, A. (2010). Seven Principles of Strategic Leadership. International Studies in Educational Administration, Vol $38,22-35$.

[227] Rafferty A.E, G. M. (2004). Dimensions of Transformational Leadership: Conceptual and Empirical Extensions. The Leadership Quarterly, 15, 329-354.

[228] Ramchandra, R., Nagamani, M., \& Sripirabaa, B. (2009). International Conference on Managing Educatiaon for Business and Commerce in a Globalised World. Strategies for Excellence. New Delhi. Mumbai. Kolkata. Chennai. Nagpur. Ahmedabad. Bangalore. Hyderabad. Lucknow: Allied Publishers Private Ltd.

[229] Rautiola, J. (2009). Effects of leadership styles and student academic achievement. School Leadership and Academic Achievement

[230] Rautiola, J. (2009, July 19). EFFECTS OF LEADERSHIP STYLES AND STUDENT ACADEMIC ACHIEVEMENT. Retrieved from $\quad$ www.nmu.edu: https://www.nmu.edu/sites/DrupalEducation/files/UserFiles/Files/PreDrupal/SiteSections/Students/GradPapers/Projects/Rautiola_James_MP.pdf

[231] Robbins, S. P. (2003). Essentials of organizational behavior. Prentice Hall.

[232] Rojas, R. (2000). Review of models for measuring organizational effectivness among for profit and non profit organizations. NonProfit management and Leadership 11(1), 97-104

[233] Rose, J., \& Gray, P. (2006). School Leadership and Student Achievement: The mediating effects of teacher beliefs. Canadian Journal of Education 29 (3), 798-822.

[234] Rowe. (2001). Creating wealth In Organizations: The Role fo Strategic leadership. The Academy of Management Executives 15 (1), 81-95.

[235] Rowe, G. (2001). Creating Wealth in Organizations: The role of strategic Leadership. The Academy of Management Executive, 8194.

[236] Rowe, W. (2001). Creating wealth in organizations: The role of strategic leadership. Academy of Management Executive 15 (1), 81-95.

[237] Rowe.G. \& Nejad.M.H. (2009). Strategic leadership: shrt-term stablity and long-term viability. Ivey Business Journal, 73 (5); 6-11.

[238] Sanders, T. J., \& Davey, K. (2011). Out of the Leadership theory joungle: a proposed meta- model of strategic leadership.

[239] Sanders, T. L. (1998). Strategic thinking and new science. New York: Free Press.

[240] Schermerhorn, J. R. (2004). Core concepts of organizational behavior. John Wiley \& Sons Inc. .

[241] Schreerens, J. (1999). School Effectiveness in Developed and Developing countries; a review of the research evidence. Netherlands: World Bank. Retrieved from web.worldbank.org/archive/website00237/.../JAAP699.DOC.

[242] Seifu, G. (2016). Assessment of the implementation of continuous assessment: the. European Journal of Science and Mathematics Education, 534-544.

[243] Selznick P. (1984). Leadership in Administration: A sociological interpretation. Berkeley: Berkely University of California Press .

[244] Senge, P. (1999). The fifth discipline: he art and practice of the leearning organization. New York: Currency Doubleday. 
[245] Serfontien, K., \& Hough, J. (2011). Nature of the Relatioship Between Strategic Leadership Operational Strategy and Organizational Performance. Sajems Ns 14, 393-405.

[246] Slawinski, N. (2007). Strategic Leadership. 297.

[247] Smaczny, T. (2001). Is an alignment between Business and IT the Appropriate paradigm to manage IT in Today's organization ? . Management decision 39 (10), 797-802.

[248] Stalk, G., Evans, P., \& Schulman, L. (1992). Competing on capabilities: the new rules of corporate strategy. Harvard Business Review, 70, 57-69.

[249] Statistics Canada. (2010). Survey Methods and Practises. Ottawa: Minister of Indurstry.

[250] Steers, R. (1975). Problems in the Measurement of Organizational Effectiveness. Administrative Science Quarterly , 546.

[251] Steyn, H., \& Wolhuter, C. (2010). Creating Sustainable Learning Environment of Schools by Strategic Planning: The Experience of Engagement by Comparative Education Team at University . South African Journal of Higher Education (24)3, 56-70.

[252] Steyn, H., Wolhunter, C., \& . (2010). Creating Sustainable Learning Environment of Schools by means of strategic planning: The experience of Engagement by Comparative Educatio Team at University,. South African Journal of Higher Education 24 (3), 56-70.

[253] Stogdil, 1. R. (1957). Leader Behaviour: Its Description and Measurement. Ohio: Bureau of Business Research. Ohio State University.

[254] Stone, G., \& Patterson, K. (2005). The history of leadership focus. Servant Leadership Research Roundtable.

[255] suskavcevic, M., \& Blake, S. (1999). Educational Leadership and Student Achievement: An Examination of the third international Maths and Science study. Internation Research Conference, Lefcosia, Cyprus, May 11-13, 2004.

[256] Tanner, S., \& Bailey, M. (2014). From ISO 9001 to World-Class Performance. London: Berforts Group.

[257] Teece, D., Pisano, G., \& Shuen, A. (1997). Dynamic Capabilities \& Strategic Management . Strategic Management Journal 18(7), 509-533.

[258] TerreBlanche, M., \& Durrheim, K. (1999). Research in Practise. Cape Town: University of Cape Town Press.

[259] The strategic position: strategic capabilities. $\quad(2007, \quad 10 \quad 15)$ Retrieved catalogue.pearsoned.co.uk/assets/hip/images/catalog/.../ECS8_C03.pdf: http://catalogue.pearsoned.co.uk/assets/hip/images/catalog/uploads/ECS8_C03.pdf

[260] Tihany L, E. A. (2000). Composition of Top Management Team and Internation Diversification. Journal of Management, 26, 11571177.

[261] Turner, A. (2003). Sampling Frames and Master Samples. United Nations Secretariat: Statistics Division.

[262] Ulrich, D., \& Barney, J. (1984). Perspectives in organizations: Resource dependency efficiency and population. Academy of Management Review, 9., 471-481

[263] UNESCO. (2010). Strategic Planning as Effective Tool of Strategic Management in Public Sector Organizations: Evidence from Public Tranist Organizatons . Administration and Society (1), 87-123.

[264] Vera, S., \& Crossan, M. (2004). Strategic Leadership and Organizational Learning. Academy of Management Reviews, Vol.29. No.2, 222-240.

[265] Verweire, K. B. (2005). Integrated Performance Management . London: SAGE

[266] Volberda, H., Morgan, R., Reinmoeller, P., Hitt, M., Ireland, R., \& Hoskisson, R. (2011). Strategic Management Competitiveness and Globalization, . Hampshire: United Kingdom: Concepts and Cases, 9th Edition.

[267] Vroom V.H. (1964). Work and Motivation. San Francisco; CA: Jossey- Bass.

[268] Wanjala, C. (2014). Strategic Planning in Schools in Kenya; Possibilities and Challenges. ISEA. Volume 47 Number1, 2014.

[269] Wanjala, C., \& Rarieya, F. (2014). Strategic Planning in Schools in Kenya:Possiblities and Challenges. Academic Edu.

[270] Warnecke, R. (2005). Sampling Frames. Encyclopedia of Biostatistics.7. DOI: 10.1002/0470011815.b2a16063.

[271] Wasserman, N. (2014). The Founder's Resource- Dependence Challenge. Harvard Business School.

[272] Waters, J., Marzano, R., \& McNulty, B. (2004). Leadership that sparks learning. Educational Leadership 61(7), 48-51.

[273] Weaver, K., \& Olson, J. (2006). Understanding paradigms used for nursing research. Journal of Advance Nursing, DOI: 10.1111/j.1365-2648.2006.03740.x.

[274] Weill, P. \&. (1998). Leveraging the New Infrastructure. Harvard Business School Press.

[275] Weiss, W. B. (2006). Transforming Military Leaders

[276] Wernerfelt, B. (1984). Reource-Based View. Strategic Management Journal, 171-80.

[277] Winston, E., \& Patterson, K. (2006). An integrative definition of leadership. Internation Journal of leadership studies.

[278] Wit, B., \& Meyer, R. (2010). STRATEGY. Process, content and context. Cheriton House, North Way, Andover, Hampshire SP10 5BE. United Kingdom: South- Western. Cencage Learning.

[279] Wong, L., Gerras, S., Kidd, W., Pricone, R., \& Swengros, R. (2003). Strategic Leadership Competencies.

[280] www.nist.gov/baldrige. (2013-2014). Retrieved from Baldrige Performance Excellence Program.

[281] Yukl G. (2002). Leadership in Organizations. Saddle- River: NJ: Prentile- Hall.

[282] Yukl, G. (1999). An evaluation essay on current conceptual weaknesses in transformational and charismatic leadership. The Leadership Quarterly, 285-305.

[283] Zaccaro, S. (2003). E- Leadership and Challenges of Leading E- Teams: Minimizing the bad and Maximizing the Good. Organanization Dynamics, 377-387.

[284] Zhu, W., Chew, I., \& Spangler, W. (2005). CEO transformational leadership and organizational outcomes:The mediating role of human-capital-enhancing human resource management. Leadership Quarterly 16(1), 39-52.

[285] Zikmunnd, W., Babin, B., Carr, L., \& Griffin, M. (2013). Business Research Methods. Mason , OH: South- Western. Cengage Learning. 